DOI: 10.1515/jolace-2015-0003

\title{
The perception of readiness for teaching profession: a case of pre-service trainees
}

\author{
Zuzana Straková \\ University of Prešov, Slovakia \\ zuzana.strakova@unipo.sk
}

\begin{abstract}
Pre-service teacher training offers various opportunities for trainees to become aware of and understand the qualities of good teaching. Towards the end of their training they should be able to identify clearly the criteria for measuring their readiness for teaching profession as well as identify their own strong and weak areas.

The author of this article presents the results of the study where the aim was to focus on the trainees perception of themselves as English language teachers based on the criteria of the EPOSTL at the end of their training when trainees receive their diploma for teaching the English language.
\end{abstract}

\section{Keywords}

self-efficacy, teacher beliefs, pre-service teacher training, self-perception, educational change

\section{Introduction}

The importance of continuous teacher development throughout the entire teaching career seems to be an indisputable necessity. Especially if one takes into consideration the changing world and lifestyles, education cannot be left aside and pretend that the changes around do not have any relevance for the way people learn. Teachers of new millennium need to be equipped with skills which would be inconceivable to most professionals in the field twenty years ago.

Change, although vital and inevitable, is never easy, whether we look at the change of a life habit or any educational aspect. Fullan (1993) explains that educators should be viewed as experts in the change dynamics or even as agents of changes. Head and Taylor (1997) see them as powerful examples to their students that change actually brings opportunities which should not be neglected. This means that teaching profession requires not only the skills of being able to cope with the change around us; moreover it requires the skills of being able to teach other people to be ready for change and to cope with it. To gain qualities like these teachers need to be involved in continuous development themselves but what seems to be even more important they need to be aware of this need already during their preservice teacher training. As Woolfolk Hoy and Spero (2005, p. 343) explain "once efficacy beliefs are established they appear to be somewhat resistant to change".

Readiness of trainees for their future profession is traditionally measured by the means teachers of tertiary education usually have at their disposal - exam grades, teaching practice feedback from supervisors as well as final evaluation at the final state exams. This study, however, aimed at looking closer at the concept of readiness from trainees' perspective based on their own experience during the teaching practice or during the methodology seminars. The aim was to measure how ready the trainees felt for the practice after they had experienced field placement and whether they felt they were prepared for the changing school reality.

The knowledge and skills the trainees gain in Methodology courses where they focus on their future profession most, are evaluated by the standard means - written tests, oral examinations, topic 
presentations, micro-teaching sessions, literature review papers, research papers, essays, a discussion chairing, etc. Still there remains the question whether all these components contribute enough to the feeling of readiness for the profession or eliminate the feeling of uncertainty in teaching and whether the structure of Methodology courses respects the changes in school environment.

This area has been a focus to many research studies although most of them defined efficacy or selfefficacy as their prime field of interest. Some research studies focused exclusively on pre-service teacher training (e.g. Gavora, 2010) while some investigated the correlation between self-efficacy of trainee teachers during the training programme and the first year of teaching (e.g. Woolfolk Hoy \& Spero, 2005). Self-efficacy is mainly understood as beliefs that a person holds about personal skills, capabilities or decision-making process one is able to perform. One of the first professionals who paid attention to this construct was Bandura (1977) and he researched the nature and structure of selfefficacy beliefs as well as the processes through which such self-beliefs operate (Pajares, 2002). Together with self-efficacy it is interesting to mention the concept of uncertainty which is not commonly the focus of the research although some studies have noted the strong influence on teacher's discomfort since they need to learn how to live with constant uncertainty concerning many aspects of their job (Jackson, 1986; Labaree, 2000; Cohen, 1989). However, by the term readiness we indicate rather the feeling of being ready for the job with the consideration of all aspects and elements which contributed to that feeling during pre-service training.

\section{Background}

Pre-service teacher training in Slovakia traditionally consists of more components - some are oriented theoretically and some focus more on application. The aim of all, however, is to contribute to building up a professional self of future teachers as well as positive attitudes towards their future profession. Methodology courses usually represent that part of pre-service teacher training which focuses mainly on the application of the core knowledge of language and literature within a classroom setting. Trainees learn how to deal with every-day classroom situations and how to design the approach to suit a certain group of learners. This study focuses on the training of future teachers of English language and literature at the Faculty of Arts in the Eastern Slovakia. Trainees have to go through several compulsory courses of EFL Methodology (e.g. single majors have six compulsory courses while double majors have three compulsory courses of EFL Methodology and they also receive training from the other subject) as well as several electives which they can choose from depending on their interest areas (e.g. using technology in the classroom, teaching young learners, using drama, using CLIL, teaching children with specific educational needs, etc.). Trainees also go through teaching practice under the supervision of qualified and experienced English language teachers at elementary and secondary schools. The amount of time they spend at schools is nine weeks altogether but it is divided into three blocks - elementary school practice, secondary school practice and the final teaching practice which takes place at both elementary and secondary schools and lasts for five weeks.

The aim of this study was to identify the level of readiness for teaching profession from trainees' perspective or how they see themselves ready to take over the duties of an English language teacher. The study thus sought the answers for these questions:

1. How do trainee teachers feel ready for their profession after the Methodology courses and the field placement?

2. Which areas/skills are left uncovered by the Methodology courses and should be given more attention?

The target group for the purpose of the study was a group of pre-service trainees in their final year of pre-service training. They have completed all compulsory and elective courses as well as their teaching practice at both elementary and secondary level. The number of respondents within the target group was 37. 


\section{Methodology}

Since the aim of this study was to focus on trainees' perception of readiness it was necessary to choose such an instrument for data collection that would allow them to reflect on the direct teaching experience in order to reveal their self-evaluation of their performance as a language teacher but still would take into consideration a wider scope of aspects involved in teaching profession. Therefore, it would not be sufficient to use regular self-evaluation sheets which trainees usually produce as a log after each lesson they teach.

The studies mentioned earlier used mainly Bandura's Teacher Self-Efficacy Scale (1977) or Gibson and Dembo's 30-item scale (1984). However, these focus mainly on teaching profession in general while we were interested in foreign language teachers instead. Therefore, we have decided to use an instrument which defines and describes such skills and capabilities that are specific for foreign language teaching. Already a decade ago the Modern Centre for European Languages in Graz designed a project aimed at producing a tool for guiding trainees' understanding of reflection - European Portfolio for Student Teachers of Languages (EPOSTL). The main objectives of the EPOSTL were stated with the focus on the trainee as follows:

1. to encourage you to reflect on the competences a teacher strives to attain and on the underlying knowledge which feeds these competences;

2. to help prepare you for your future profession in a variety of teaching contexts;

3. to promote discussion between you and your peers and between you and your teacher educators and mentors;

4. to facilitate self-assessment of your developing competence;

5. to provide an instrument which helps chart progress. (Newby et al., p. 5)

We have had a prior experience with this tool since it was piloted as a supplement of a teaching practice portfolio (for more details see Straková, 2010). The EPOSTL, thus, seemed to be the instrument which might guide trainees through the process of revealing their own perception of teaching qualities at the end of their pre-service training identifying the areas where they felt strong or weak. For this study we used the second part of the EPOSTL, the set of 195 'can-do' descriptors. These descriptors are grouped around seven areas:

- Context - Decisions relating to teaching are strongly influenced by the educational and social context in which teachers work. This context is mainly predetermined by the requirements in the national and/or local curricula. However, there may also be international recommendations and documents, which will need consideration. Institutional constraints are another factor to be considered as they may have considerable impact on the work of teachers. A further dimension of the language learning context includes the overall aims and specific needs of learners, which, when identified, determine what the teacher does. A sample "can-do" descriptor: I can understand the requirements set in national and local curricula.

- Methodology - Methodology is the implementation of learning objectives through teaching procedures. It is based on principles deriving from theories of language description, language learning and language use. Methodology may focus on how teachers can deal with the four main skills of speaking, writing, listening and reading, as reflected in the categorisation of this section. However, in written and oral communication in the classroom two or more skills will usually be integrated and are rarely treated in isolation. A sample "can-do" descriptor: I can create a supportive atmosphere that invites learners to take part in speaking activities.

- Resources - This section is concerned with a variety of sources teachers can draw on in the process of locating, selecting and/or producing ideas, texts, activities, tasks and reference materials useful for their learners. A sample "can-do" descriptor: I can select those texts and language activities from coursebooks appropriate for my learners. 
- Lesson Planning - Planning activities depends on both learning objectives and content and requires teachers to consider how learners can reach the objectives through the material chosen. When planning a lesson, the teacher's knowledge of language learning theory, a wide scope of methodology, resources and learner activities are as important as knowledge of the individual learner's abilities. A sample "can-do" descriptor: I can plan specific learning objectives for individual lessons and/or for a period of teaching.

- Conducting a Lesson - The section on conducting a lesson focuses on what teachers do in Modern Language classrooms and on the skills required. The first of these, expressed as a broad category, is the implementation of a lesson plan. This section also identifies as significantly important teachers' interactions with the class during the teaching and learning. The final group of descriptors focuses on the teacher's use of the target language in class. A sample "can-do" descriptor: I can start a lesson in an engaging way.

- Independent Learning - Language learning in a school context is both a matter of learning individually and in cooperation with peers, as well as independent learning with the guidance of a teacher. This means giving the individual learner or groups of learners a chance to take charge of aspects of their own learning processes in order to reach their full potential. Autonomous learning is an integral part of learning foreign languages, not an additional method of teaching. A sample "can-do" descriptor: I can help learners to reflect on and evaluate their own learning processes and evaluate the outcomes.

- Assessment of Learning - This category is concerned with the choices which the teacher has to make when assessing learning processes or outcomes of learning. These choices relate to broad questions such as what to assess, when to assess, how to assess and how to use the information provided by the assessment process to support learning and to improve one's own teaching. A sample "can-do" descriptor: I can identify strengths and areas for improvement in a learner's performance (Newby et al., p. 14-51).

The trainees were given the EPOSTL when they attended the final teaching practice and they were supposed to take a note of how successful or ready they felt within individual descriptors. Since the EPOSTL is meant for self-reflection and since it understands the development as an on-going process, the bars accompanying each descriptor indicate this development by the way the trainees are expected to fill it in: "Each descriptor is accompanied by a bar, which will help you to visualise and chart your own competence. You can colour in the bar according to your own assessment. This may take place at different stages of your teacher education" (Newby et al., 2007, p. 6).

Since we aimed at making the level of readiness as clear as possible the trainees were asked not only to colour the bars but also to rate their feeling of readiness by the number. That should make it clear how they evaluated their skills and abilities based on the immediate teaching experience on the scale of 0 to 100 .

\section{Discussion of the results}

In general, it can be concluded that trainees perceive themselves very well prepared for teaching profession and they gave themselves an average rating of 79 on a scale of 0 to 100 . What is even more surprising is that as many as $72 \%$ of trainees involved in the study recorded at least one descriptor at 100. The general evaluation within this group varied from 56 to 96 for all descriptors. The average for all descriptors within this group is 96 which seems to be extremely high.

On the other hand, $27 \%$ of trainees recorded all descriptors at lower level than 100 . Their general score ranged from 60 to 85 and the average for this group was 70. This could lead us towards the conclusion that trainees feel quite confident before starting their career which can contribute to positive attitudes towards the profession in general. 


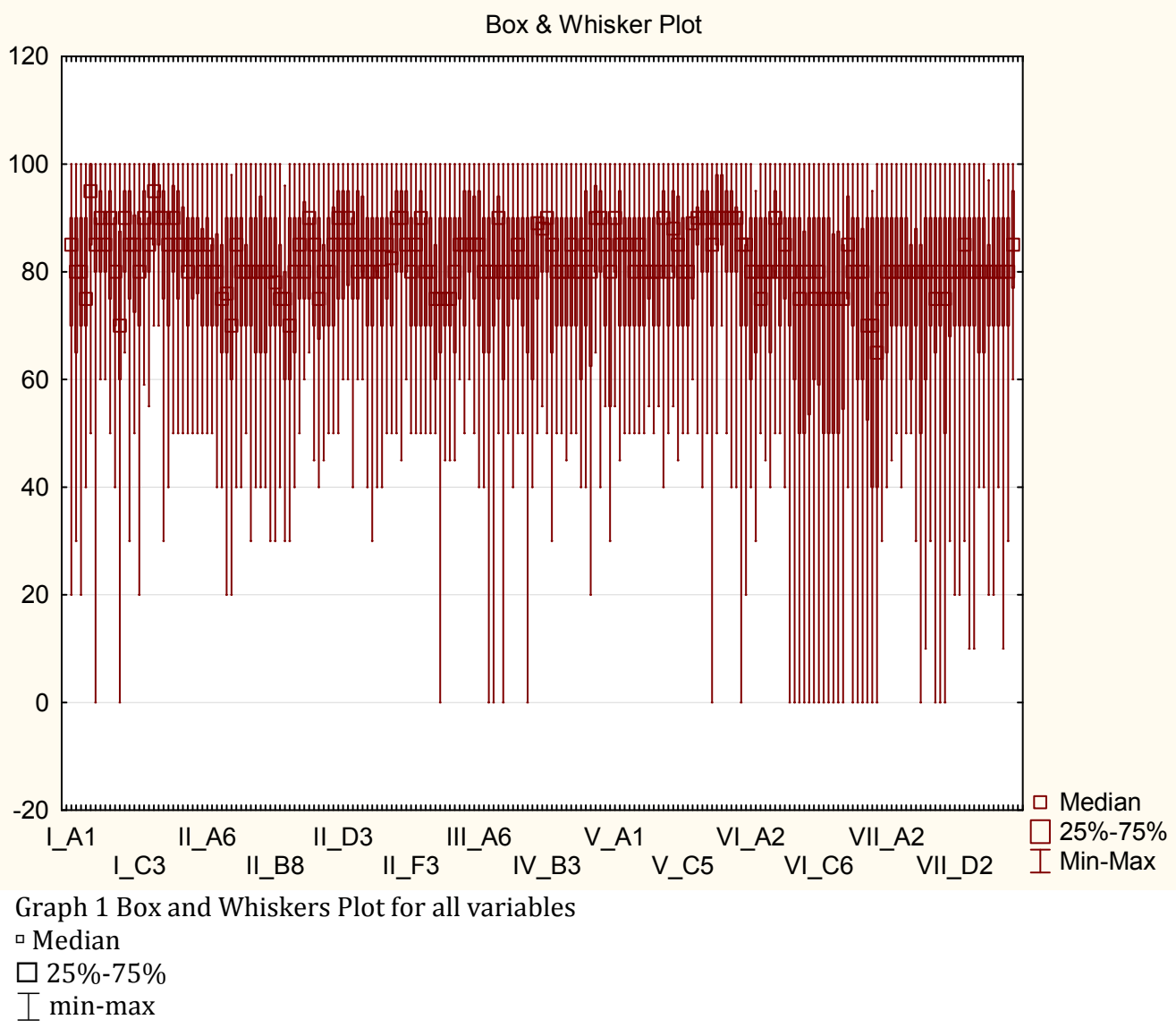

As can be seen from this graph, most descriptors scored very high values even though the diversity in evaluation was extremely high as well. $75 \%$ of the scores fall below the upper quartile and $25 \%$ of scores fall below the lower quartile. Several descriptors ranged from 0 to 100 and it can be especially seen within the area of Independent Learning and Assessment.

The individual areas demonstrate the correlation between the focus of Methodology courses and the perception of trainees how ready they feel within seven individual areas (defined by EPOSTL):

$\begin{array}{llll}\text { Context } & 82 & \text { Resources } & 79 \\ \text { Conducting a Lesson } & 82 & \text { Assessment of Learning } & 76 \\ \text { Lesson Planning } & 80 & \text { Independent Learning } & 71 \\ \text { Methodology } & 79 & & \end{array}$

It can be implied that the highest scores for Context and Conducting a Lesson might be a result of the attention which is being paid to these aspects during the training. The least scored areas - Assessment and Independent Learning - at the same time indicate that trainees do not have enough space to practise the decision making skills in developing learner autonomy as well as evaluating their progress. This seems to be a logical conclusion bearing in mind the content of the pre-service training and still it seems that trainees have overestimated their skills since 76 and 71 scored for these two areas do not really give a true and corresponding reflection of how the trainees really are able to perform. Some of 
the lowest scores were as well connected to extra-curricular activities, such as school trips, school projects, etc. which students do not normally have a chance to experience during their field placement.

Looking closer at individual descriptors within each area it might be interesting to notice which descriptors received the highest and which the lowest rates.

The highest rates within individual descriptors were reached in the area of Context and Conducting a Lesson, e.g.:

\begin{tabular}{|l|l|}
\hline I can accept feedback from my peers and mentors and build this into my teaching. & 91.9 \\
\hline I can understand the personal, intellectual and cultural value of learning other languages. & 91.4 \\
\hline I can decide when it is appropriate to use the target language and when not to. & 90.0 \\
\hline I can conduct the lesson in the target language. & 89.1 \\
\hline $\begin{array}{l}\text { I can observe my peers, recognize different methodological aspects of their teaching and offer them } \\
\text { constructive feedback. }\end{array}$ & 89.1 \\
\hline
\end{tabular}

Table 1: The highest rated descriptors

The lowest rates in individual descriptors were located around the area of Independent learning and specifically in connection with school trips and school projects.

\begin{tabular}{|l|l|}
\hline $\begin{array}{l}\text { I can evaluate the learning outcomes of school trips, exchanges and international cooperation } \\
\text { programmes. }\end{array}$ & 60.3 \\
\hline $\begin{array}{l}\text { I can help to organise the school exchanges in cooperation with relevant resource persons and } \\
\text { institutions. }\end{array}$ & 61.3 \\
\hline I can set aims and objectives for school trips, exchanges and international cooperation projects. & 63 \\
\hline I can plan and structure portfolio work. & 63.8 \\
\hline I can plan and organise cross-curricular project work myself or in cooperation with other teachers. & 66.3 \\
\hline
\end{tabular}

Table 2: The lowest rated descriptors

When we look at the area of Conducting a Lesson which can be interesting for us as a feedback on which elements of Methodology courses need more focus we can see that in this area descriptors are divided into subcategories: A - Using lesson plans (1), B - Content (2), C - Interaction with learners (3), D - Classroom management (4), E - Classroom language (5). 


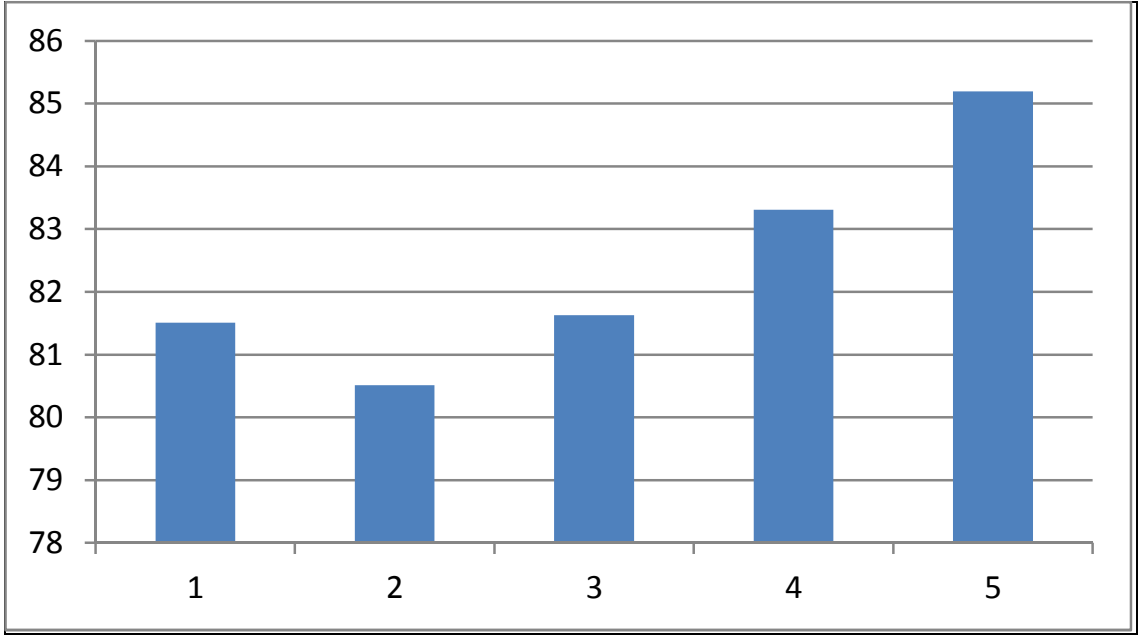

Graph 2: The average for each area of the EPOSTL

Individual descriptors within the area Conducting a Lesson provide more details on where exactly trainees feel confident and thus it brings more information on how to modify the focus of seminars in individual Methodology courses. For instance, within the descriptors D5 (I can supervise and assist learners' use of different forms of ICT both in and outside the classroom) and E6 (I can encourage learners to relate the target language to other languages they speak or have learned where and when this is helpful.) it is interesting to note that the scores varied from 0 to 100 but 0 rates were not awarded by the same student in both cases.

Box \& Whisker Plot

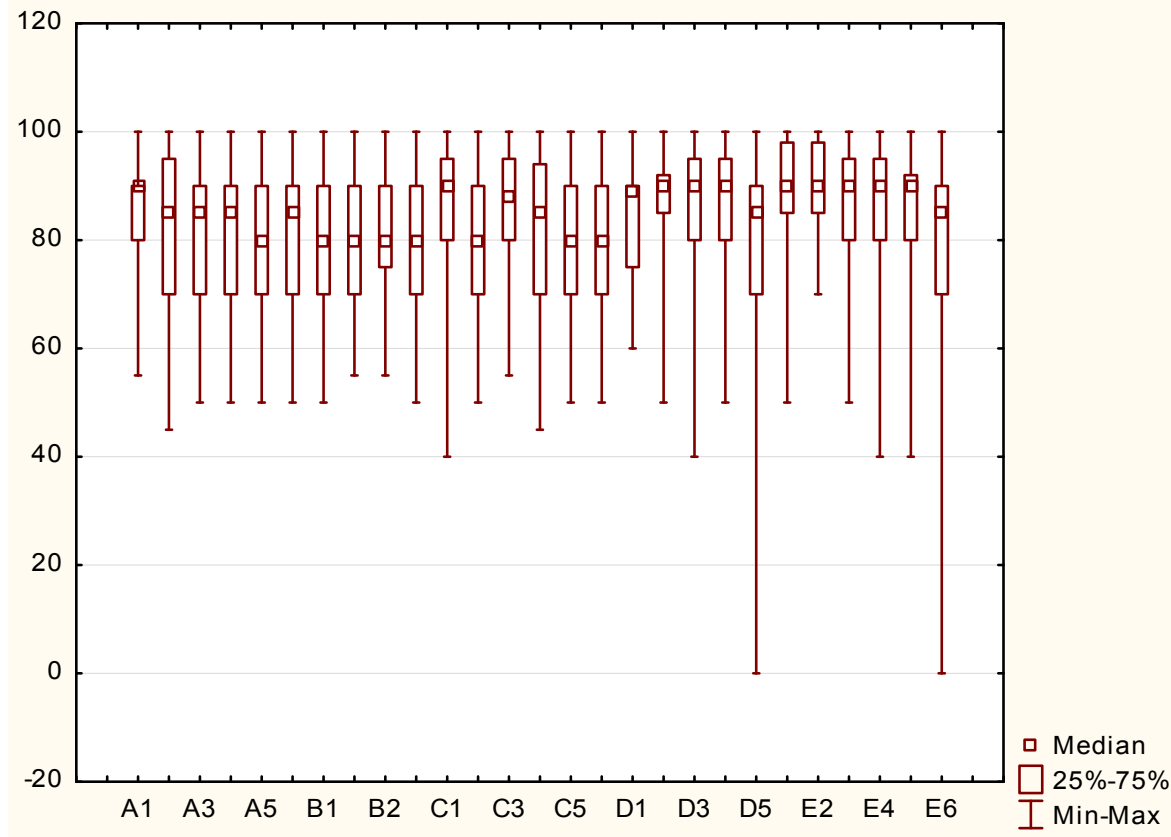

Graph 3: Box and Whisker Plot for the EPOSTL area Conducting a Lesson 
The descriptor E2 (I can decide when it is appropriate to use the target language and when not to.) suggests that most students feel confident here and this can be also said about the descriptor D2 (I can create opportunities for and manage individual, partner, group and whole class work.). It is also evident from the graph 3 as well as from the data given in table 3 . The least value was 70 and maximum 100. The average value was 90.05 . The box plot is comparatively short what suggests that overall students have a high level of agreement with each other. Here we can also mention the lower and upper quartiles with borders at 85 and 98 , where $50 \%$ of respondents can be located. Median value is 90 , what means that half of the students evaluated themselves between 90-100 (the other 50\% in the range 70-90).

\begin{tabular}{|c|c|c|c|c|c|c|}
\hline \multirow{2}{*}{ Variable } & \multicolumn{6}{|c|}{ Descriptive Statistics (EPOSTL_kat) } \\
\hline & Valid N & Mean & Median & Minimum & Maximum & Std.Dev. \\
\hline V_A1 & 37 & 84.54054 & 90.00000 & 55.00000 & 100.0000 & 11.34214 \\
\hline V_A2 & 37 & 82.43243 & 85.00000 & 45.00000 & 100.0000 & 14.88762 \\
\hline V_A3 & 37 & 80.81081 & 85.00000 & 50.00000 & 100.0000 & 15.08649 \\
\hline V_A4 & 37 & 81.18919 & 85.00000 & 50.00000 & 100.0000 & 14.74569 \\
\hline V_A5 & 37 & 80.24324 & 80.00000 & 50.00000 & 100.0000 & 13.73642 \\
\hline V_A6 & 37 & 79.83784 & 85.00000 & 50.00000 & 100.0000 & 14.30717 \\
\hline V_B1 & 37 & 79.24324 & 80.00000 & 50.00000 & 100.0000 & 13.51215 \\
\hline V_B2 & 37 & 82.43243 & 80.00000 & 55.00000 & 100.0000 & 12.01744 \\
\hline V_B3 & 37 & 80.16216 & 80.00000 & 50.00000 & 100.0000 & 12.67875 \\
\hline V_B4 & 37 & 80.21622 & 80.00000 & 55.00000 & 100.0000 & 11.02052 \\
\hline V_C1 & 37 & 86.32432 & 90.00000 & 40.00000 & 100.0000 & 13.51553 \\
\hline V_C2 & 37 & 79.64865 & 80.00000 & 50.00000 & 100.0000 & 14.04203 \\
\hline V_C3 & 37 & 84.89189 & 88.00000 & 55.00000 & 100.0000 & 13.10594 \\
\hline V_C4 & 37 & 81.89189 & 85.00000 & 45.00000 & 100.0000 & 15.28577 \\
\hline V_C5 & 37 & 78.78378 & 80.00000 & 50.00000 & 100.0000 & 15.04278 \\
\hline V_C6 & 37 & 78.24324 & 80.00000 & 50.00000 & 100.0000 & 15.46574 \\
\hline V_D1 & 37 & 83.13514 & 89.00000 & 60.00000 & 100.0000 & 12.13847 \\
\hline V_D2 & 37 & 86.43243 & 90.00000 & 50.00000 & 100.0000 & 11.46623 \\
\hline V_D3 & 37 & 85.62162 & 90.00000 & 40.00000 & 100.0000 & 14.44213 \\
\hline V_D4 & 37 & 84.70270 & 90.00000 & 50.00000 & 100.0000 & 13.57257 \\
\hline \multirow[b]{2}{*}{ Variable } & \multicolumn{6}{|c|}{ Descriptive Statistics (EPOSTL_kat) } \\
\hline & Valid N & Mean & Median & Minimum & Maximum & Std.Dev. \\
\hline V_D5 & 37 & 76.64865 & 85.00000 & 0.00000 & 100.0000 & 23.21065 \\
\hline V_E1 & 37 & 89.10811 & 90.00000 & 50.00000 & 100.0000 & 11.56331 \\
\hline V_E2 & 37 & 90.05405 & 90.00000 & 70.00000 & 100.0000 & 8.83788 \\
\hline V_E3 & 37 & 85.62162 & 90.00000 & 50.00000 & 100.0000 & 12.44399 \\
\hline V_E4 & 37 & 84.45946 & 90.00000 & 40.00000 & 100.0000 & 14.38285 \\
\hline V_E5 & 37 & 84.81081 & 90.00000 & 40.00000 & 100.0000 & 12.77767 \\
\hline V_E6 & 37 & 77.10811 & 85.00000 & 0.00000 & 100.0000 & 22.42987 \\
\hline
\end{tabular}

Table 3: Descriptive Statistics for the EPOSTL area Conducting a Lesson 
One interesting fact that can be noticed from the table above, is that as many as 11 items show median at the level 90.00 which means that more than $50 \%$ of trainees rated themselves at this level or even higher.

\begin{tabular}{|c|c|c|c|c|c|c|}
\hline \multirow{3}{*}{ Variable } & \multicolumn{6}{|c|}{ Correlations (EPOSTL_katego.sta) Marked correlations are significant at $p<.01000$} \\
\hline & \multicolumn{6}{|c|}{$\mathrm{N}=37$ (Casewise deletion of missing data) } \\
\hline & I & III & IV & $\mathrm{V}$ & $\mathrm{VI}$ & VII \\
\hline \multicolumn{7}{|l|}{1} \\
\hline \multirow[t]{2}{*}{$\|$} & .9467 & & & & & \\
\hline & $p=.000$ & & & & & \\
\hline \multirow[t]{2}{*}{ III } & .9432 & .9978 & & & & \\
\hline & $p=.000$ & $p=0.00$ & & & & \\
\hline \multirow[t]{2}{*}{ IV } & .8421 & .9008 & .9162 & & & \\
\hline & $p=.000$ & $p=.000$ & $p=.000$ & & & \\
\hline \multirow[t]{2}{*}{ V } & .8727 & .9289 & .9363 & .9773 & & \\
\hline & $p=.000$ & $p=.000$ & $p=.000$ & $p=0.00$ & & \\
\hline \multirow[t]{2}{*}{$\mathrm{VI}$} & 6180 & .6680 & .6732 & 6999 & .7132 & \\
\hline & $p=.000$ & $p=.000$ & $p=.000$ & $p=.000$ & $p=.000$ & \\
\hline \multirow[t]{2}{*}{ VII } & .7573 & .8069 & .8170 & .8367 & .8037 & .7657 \\
\hline & $p=.000$ & $p=.000$ & $\mathrm{p}=.000$ & $\mathrm{p}=.000$ & $\mathrm{p}=.000$ & $p=.000$ \\
\hline
\end{tabular}

Table 4: Correlations between individual areas

Looking at correlations (see Tab. 5) it might be said that in general there are strong correlations between the areas, e.g. there is nearly perfect correlation between the area II (Methodology) and III (Resources). The weakest level of relationship can be noticed between the area I (Context) and area VI (Independent learning) although even this relationship can be seen as a moderate correlation between the variables $(0.6180)$.

\section{Conclusions}

Being ready to take over the duties of teaching profession at the beginning of the career seems to be very important in order to start building and maintaining positive attitude towards someone's job. Especially when it comes to educators it seems that due to many factors affecting the teaching profession it faces the risk of disillusion, feeling a high level of uncertainty and burnout effect.

Uncertainty of how to act as a teacher or feelings of not being prepared well for the profession did not seem to be present within the group of pre-service teacher trainees at the end of their training. It might be interesting to check on their progress after one year of teaching in order to see whether their strong belief in themselves had changed or got affected by the real life of a teacher. Novice teachers seem to enter the profession with the courage which might later decline due to the complexity of tasks and administrative agendas and school requirements. This fact was highlighted in the Woolfolk Hoy and Spero's findings (2005) and might be relevant also for this study.

However, even though it can be concluded that trainees overestimated their abilities in some areas, and that the perception of their self-efficacy is at very high level, the aim of the study was oriented more on the content of the Methodology course and the consideration whether trainees during their training get what is useful for them in the practice. For tutors it brings the feedback that the structure of the Methodology courses and the content which these courses focus on match the needs of every day teaching practice and reflect up-to-date reality. There is still a lot to consider especially within two 
areas which scored the lowest grades - Learner independence and Assessment. There might be more space created for the development of these aspects.

Last but not least using the EPOSTL as an instrument for measuring their self-efficacy disclosed that trainees considered beneficial the reflection on individual aspects of teacher's work. Their feedback supported the decision to use EPOSTL as a part of the teaching practice portfolio since it brought them closer to thinking about their own strengths and weaknesses: „it was kind of clearer to me which things to think about in connection to my teaching. Before in the self-evaluation I just stated that it was fine and I achieved my aims, but this time I had to be really specific...”, , there were too many things I could not answer properly because I had no experience with it (e.g. about school trips) so I just guessed..."

\section{Acknowledgment}

This work was supported in part by a grant from KEGA 006PU-4/2012.

\section{References}

Bandura, A. (1977). Self-efficacy: toward a unifying theory of behavioral change. Psychological Review, 84, 191-215.

Bandura, A. (1997). Self-efficacy: the exercise of control. New York: Freeman.

Borg, M. (2001). Teachers' beliefs. ELT Journal, 55(2), 186-187.

Bullough, R. V., Young, J., \& Draper, R. J. (2004). One-year teaching internships and the dimensions of beginning teacher development. Teachers and Teaching: Theory and Practice, 10(4), 365-394.

Breen, M. P., \& Littlejohn, A. (Eds.) (2000). Classroom Decision-making. Cambridge: Cambridge University Press.

Cohen, D. K. (1989). Teaching practice: Plus que ça change. In Jackson, P. W. (Ed.), Contributing to educational change: Perspectives on research and practice (pp. 27-84). Berkeley, CA: McCutchan.

Floden, R. \& Clark, C. M. (1988). Preparing Teachers for Uncertainty. Teachers College Record, 89(4), 505-524

Fullan, M. (1993). Change Forces: Probing the Depths of Educational Reform. London: The Falmer Press.

Gavora, P. (2010). Slovak pre-service teacher self-efficacy: theoretical and research considerations. The New Educational Review, 21(2), 17-30.

Gee, J. P. (2000). Identity as an analytic lens for research in education. Review of Research in Education, 25(1), 99-125.

Gibson, S. \& Dembo, M. (1984). Teacher efficacy: a construct validation. Journal of Educational Psychology, 76(4), 569-582.

Head, K. \& Taylor, P. (1997). Readings in Teacher Development. Oxford: Heinemann English Language Teaching.

Jackson, P. W. (1986). The Practice of Teaching. New York: Teachers College Press.

Kolb, D. A. (1984). Experiential Learning: Experience as the Source of Learning and Development. New Jersey: Prentice Hall, Inc.

Labaree, D. F. (2000). On the Nature of Teaching and Teacher Education: Difficult Practices That Look Easy. Journal of Teacher Education, 51(3, May/June 2000), 228-233.

Lanas, M. \& Kelchtermans, G. (2015). "This has more to do with who I am than with my skills" - Student teacher subjectification in Finnish teacher education. Teaching and Teacher Education, 47(April 2015), 22-29.

Newby, D., Allan, R., Fenner, A., Jones, B., Komorowska, H., \& Soghikyan, K. (2007). European Portfolio for Student Teachers of Languages: A reflection tool for language teacher education. Council of Europe.

Pajares, F. (2002). Overview of social cognitive theory and of self-efficacy. Retrieved from http://www.emory.edu/EDUCATION/mfp/eff.html 
Peters, J. H. (2012). Are They Ready? Final Year Pre-service Teachers' Learning about Managing Student Behaviour. Australian Journal of Teacher Education, 37(9). Retrieved from http://dx.doi.org/10.14221/ajte.2012v37n9.2

Richards, J. \& Lockhardt, Ch. (1995). Reflective teaching in second language classrooms. Cambridge: Cambridge University Press.

Settlage, J., Southerland, S. A., Smith, L. K. \& Ceglie. R. (2009). Constructing a Doubt-free Teaching Self: Self-Efficacy, Teacher Identity, and Science Instruction Within Diverse Settings. Journal of Research in Science of Teaching, 46(1), 102-125.

Straková, Z. (2010). European Portfolio for Student Teachers of Languages and its Benefits for Preservice Teacher Training. English Matters, Prešov: Prešovská univerzita v Prešove.

Williams, M. \& Burden, R. (1997). Psychology for Language Teachers. Cambridge: Cambridge University Press.

Woods, D. (1996). Teacher Cognition in Language Teaching. Cambridge: Cambridge University Press.

Woolfolk Hoy, A. \& Spero, R. B. (2005). Changes in teacher efficacy during the early years of teaching: A comparison of four measures. Teacher and Teaching Education, 21, 343-356.

\section{Contact}

Assoc. prof. Zuzana Straková, PhD.

Institute of British and American Studies

Faculty of Arts, Univeristy of Prešov

17. novembra 1, 08001 Prešov, Slovakia

zuzana.strakova@unipo.sk 